\title{
Problems and Countermeasures in the Teaching of College Accounting Computerization
}

\author{
Wei Zheng \\ School of Economics \& Management, Changchun University of Science \& Technology \\ Changchun 130022, China \\ E-mail: zwcust@163.com
}

Xin Zhang

Department of Finance, Changchun University of Science \& Technology

Changchun 130022, China

Received: March 2, 2011 Accepted: March 20, 2011 doi:10.5539/ass.v7n7p235

\begin{abstract}
The course offering, the course content, the teaching method, the teaching software, the teacher power, and the practical teaching mode about the teaching of accounting computerization in colleges are analyzed first, and then corresponding solutions are proposed in this article.
\end{abstract}

Keywords: Teaching of accounting computerization, Problems, Countermeasures

With the increasingly popularization of accounting computerization, the accounting computerization has not been the simple combination of accounting and computer, and it is a comprehensive subject including the communication science, the enterprise management, and the market operational research. Its extension is not the simple financial management system, but develops to the enterprise resource plan (ERP), even to the large and trans-regional and trans-industrial networking accounting information processing system among different enterprises. Therefore, the education direction of the accounting computerization in the network time in colleges should be reoriented.

The college with the education of accounting computerization is the base to cultivate multi-layer accounting computerization talents, and it is very important and necessary to develop the practical training of accounting computerization and enhance students' practical handing ability. The course of accounting computerization evolves wide knowledge, and it is based many courses such as "computer application base", "database management system", "accounting principle", "financial accounting", and "handmade simulation and experiment of accounting". With the advent of knowledge economic times and the development of information technology, and the theoretical knowledge and the information processing technology of accounting computerization also develop continually, and to quicken the construction of accounting computerization has been an important task in the accounting construction of China. Because the position of accounting computerization is more and more important in the enterprise accounting, and it has been the necessary tendency for the financial work, the composite accounting talents who know not only the accounting theory but also the computer technology will be the key to realize the accounting computerization.

\section{Problems existing in the present teaching of accounting computerization}

Through many years' practice in the teaching process, following aspects have been found to impact the teaching effect.

\subsection{Students know little about the software of accounting computerization}

At ordinary times, teachers only teach students for basic theoretical knowledge, and students most contact theoretical knowledge, and know little about the simulation software, so when most students don't know what they should do when they enter into the study part of basic practical skills. In the teaching, students only know the knowledge temporarily, and if teachers teach more, students will forget the former approaches, and cannot independently and successfully operate all approaches. 


\subsection{Course offering is not scientific}

The course of accounting computerization evolves wide knowledge, and it is based many courses such as "computer application base", "database management system", "accounting principle", "financial accounting", and "handmade simulation and experiment of accounting". But at present, many colleges cannot consider the time of the computer course and the accounting course enough, and students will not grasp the basic knowledge sufficiently, which will influence the teaching effect of accounting computerization.

\subsection{Teaching mode is simplex}

At present, in the teaching process of accounting computerization course, the traditional teaching mode mainly includes the classroom teaching and the computer excise. The classroom teaching generally focuses on teachers' teaching, and students only listen, and the computer excise almost means that students only repeat the operation excise according to teachers' instruction and teaching, without interaction between teachers and students, which cannot stimulate students' study enthusiasm.

\subsection{Teaching software is deficient}

The teaching software used in colleges is the demonstration-editions of the commercial software from various financial software companies, and there is almost not the software specially designed for the teaching of accounting computerization. The demonstration-edition software belongs to single-user-edition software, so students will feel unfamiliar for the networking software. However, most users use the network-edition software of accounting computerization in the society, so students feel it is hard to apply the knowledge what they learned in the colleges, and the employed difficulty will be increased.

\subsection{Practical teaching is hard to be obtained}

Generally, the practice teaching of the accounting computerization gives priority to the content of teaching materials, and the content of practical teaching is still set up according to the subject-type course system, including the homework-type excise and validation of the knowledge what students have studied, so some students will copy and deal with these excises, and they could not independent think about the excises and enhance their practical handing ability.

\subsection{Teachers' quality is urgent to be enhanced}

The characteristics of the course of accounting computerization determine the teachers should not only possess professional accounting knowledge, but also grasp certain computer skills. Most teachers in this major directly teach their students after they graduated from the college and their knowledge all come from books and at the same time, they lack in systematic study of the computer technology, and the composite professional talents with the knowledge of accounting and the knowledge of computer are very rare. Furthermore, many young teachers have not practice and experiences, and they don't know how to apply the accounting computerization in enterprise, and in the teaching, they can only teach students the basic operations one step to one step by repeating what the books says, and practice could not be integrated with theory, and deep understandings will not certainly be achieved.

\section{Countermeasures for these problems in the teaching of accounting computerization}

\subsection{Students should know a lot about the software of accounting computerization}

Aiming at the situation that students know little about the software of accounting computerization, when teachers teach the basic theoretical knowledge, they should adopt the mode combining the multimedia with cases, and simply introduce the popular and current financial software in the society to students and make them have a sensible cognition, and leave homework requiring students to seek relative financial software to make them know more about the software of accounting computerization, and establish a model for students to study the course better.

\subsection{Course offering should be reasonable and scientific}

As an application subject with strong practicability and pertinence, the accounting computerization must design its course content based on cultivating students' ability. Generally, the accounting computerization should be based on the accounting theory, the computer base, and the system development. But at present, many colleges could not offer sufficient time for the computer course and the accounting course, and in the limited teaching time, students only can study some basic principles and simple operations, far from system grasp and skilled operation. Especially, the computer course is far from the students who are major in the accounting. Because the accounting computerization needs more computer knowledge, the teaching effect will certainly be influenced without sufficient basic knowledge of computer. 


\subsection{Reasonably utilizing the multimedia teaching}

The multimedia teaching is the active reflection of teaching to the development of information society, and it changed traditional teaching mode of "chalk + blackboard". It can teach figures and things which are hard to be expressed by the traditional mode to students by the cubic, dynamic, and visual way.

When teaching students the accounting computerization or implementing the projection teaching by multimedia, teachers can let students to participate in them, and leave students sufficient space and time to think and discuss the content, and sufficiently mobilize students' study enthusiasm, and strengthen students' independent thinking and decision-making ability, and make them to apply the theoretical knowledge into practical work, avoiding duck-feeding teaching. In addition, before implementing the case teaching by the multimedia form, teachers can arrange students to watch the disk and know well the operation approaches, and demonstrate the concrete operation flow, and emphasize those special items, and analyze the causes of students' usual mistakes, and help them to find out the solutions by using their knowledge. And when demonstrating the operation, students can explain the operation properly, so students can focus the study, and the practice effect will be better.

2.4 Reforming the teaching methods of the accounting computerization course and enhancing students' application skills

After teaching one module or a part of teaching content, teachers should arrange the experiment course reasonably, and before each computer excise, teachers should allocate concrete tasks or definite experiment requirements. Except for grasping basic operation methods, students should learn how to use "help" in the software to enhance their ability to solve problems, and deeply understand the operation process of software by combining with theoretical knowledge.

The simulation characteristic should be emphasized in the experiment of accounting computerization, and the main aim of this course should be to enhance the operation skills and professional ability, and cultivate students' comprehensive ability on some posts, i.e. the ability to solve practical problems on the professional post. The experiment course should simulate the future work flow, and work environment, the functional post, and the post requirements, and really realize the zero-distance between the classroom teaching and the post requirements.

At present, there are many popular financial software types, but because of some practical situations, the software specially designed for the accounting teaching is still deficient, and the teaching software used in colleges belongs to the demonstration-editions from various financial software companies, and the practical users of software belong to network-edition users. Even if some colleges would purchase expensive network-edition financial software in teaching, but this network-edition has not excise function, and students could not achieve mastery thorough a comprehensive study of the subject. In this situation, teachers can select one type of excellent current financial software as the major teaching object, and select other two types of financial software in the experiment room for excise, and let students to compare these types of software, and understood the same operation flow behind different types, so students can more easily grasp the financial software in the future work post.

\subsection{Increasing the dynamic communication opportunity with the society}

The current education mode still belongs to knowledge irrigation type. Most teachers have few opportunities for training and communication, and the knowledge what they are teaching is old and laggard, and it is hard to advance with the times for students.

First, colleges should increase the opportunities of dynamic communication between teachers and students with the society, and relative teachers should study the financial software in the financial software companies for some times, and participate in the implementation work of large financial information system. Second colleges should invite technical personal in the financial accounting software companies to hold technical lectures, and invite senior accountants, registered accountants, and software engineers as the part-time faculties to instruct students' practice. Third, colleges should arrange students to visit the enterprises with good accounting computerization, and invite relative personal to explain the operation flow about the accounting computerization for students, and deepen students' impression for the accounts, certificates, and tables which are being used in enterprises. Some students can also use the vocation to practice in the enterprises which have implemented the accounting computerization, and operate the practical software in the enterprises, and increase their operation ability and practical experiences.

\subsection{Strengthening the construction of the teaching team}

Aiming at the actuality that the theoretical knowledge could not combine with the practical skills perfectly, colleges should train students from all directions, for example, visiting other colleges for study and 
communication, investigating the enterprises which have implemented the accounting computerization, inviting professional talents of accounting computerization to report their experiences, and encouraging teachers to enhance their knowledge level and teaching skills. Only to update and compensate knowledge, teachers can teach the updated knowledge to students, realize the talent cultivation object, and adapt the development requirement of accounting computerization.

All in all, the accounting computerization is a comprehensive subject with strong operability. In the computer environment, the demand for the composite talents of accounting is urgent increasingly. How to enhance students' practice capacity and cultivate students as the practical talents with higher level and morality will be the first task for college teachers. As the soul engineer of imparting knowledge and educating people, teachers should pay more attention to the new requirements in the modern society, continually improve the education modes and teaching methods, enhance the teaching quality and students professional skills and operation level, and make students with better ability of relearning and better creativity, which can fulfill the demands of the society for the accounting talents.

\section{References}

Chang, Shijian. (2002). Application of Accounting Computerization. Dalian: Dongbei University of Finance and Economics.

Cheng, Xiwu \& Zhou, Jingchao. (2001). Research on Many Problems in the Teaching of Accounting Computerization. China Computerized Accounting, No. 10.

Li, Changshan. (2009). Tutorial of Accounting Computerization. Changchun: Jilin People's Press.

Liu, Chenghuan. (2001). Study on the Problem How to Enhance the Teaching Quality of the Course of Accounting Computerization. China Computerized Accounting, No. 8.

Niu, Dan. (2006). Problems and Improvement Measures about the Teaching of Accounting Computerization. China Management Informationization, No. 4. 